\title{
Features of Drivers Post-Accident Syndrome
}

\author{
Pavel Pegin ${ }^{1 *}$, and Olga Pegina ${ }^{2}$ \\ ${ }^{1}$ Saint Petersburg State University of Civil Aviation, 38, Pilotov str, Saint Petersburg, 196210, Russia \\ ${ }^{2}$ Accreditation Center of business education 3 "A", nab. Obvodnoy channel, 165 - 7, Saint \\ Petersburg, 190005, Russia
}

\begin{abstract}
According to long-term observations of drivers - participants in road accidents, the new interpretation of the generally accepted definition of post-accident syndrome is proposed and the criteria for this concept defined. The methods and ways of removing the driver out of the postaccident syndrome are formulated. The classification of post-accident syndrome is formulated according to statistics analysis. The new term "psychological severity of the accident" was proposed for discussion.
\end{abstract}

\section{Introduction}

Every year in Russia more than 150000 traffic accidents are registered with about 190000 drivers participating. For the most of them it is the first accident. To get into an accident is an emotional stress of different category, so each particular driver has to overcome this stress by himself.

According to the rule "five - five - ninety" about 5 per cent of drivers see an accident as an inevitability of the traffic, that's why they are not subject to strong emotional stress leading to any after-effects. But for 5 per cent of them it is a shock resulting in the refusal to ever drive again. The rest 90 per cent of drivers caught in an accident would adopt to these new circumstances and continue to drive according to their new experience [1]. And these new feelings may be of quite opposite nature: from dead fear in sight of a driving vehicle or a place of an accident to the likes "nothing can happen to me at all" [2]. So to say, every year about 170000 drivers in Russia are left to themselves to overcome postaccident syndrome.

\section{Theory}

It is necessary to specify the term of post-accidental syndrome. We propose the following definition: post-accident syndrome is a psychological disorder, a mental trauma and (or) emotional anesthesia, resulted from an accident and meaning that a driver feels constant anxiety and fear.

Which is expressed in the following criteria:

-a driver is afraid of oncoming and passing vehicles;

-a driver is worried and annoyed with a process of driving a car;

*Corresponding author: ppavel.khv@gmail.com 
- a driver feels a lack of interest to drive although he could look calm;

- a driver shows anxiety, rancor and shame, he infinitely blames himself, endlessly turning the experienced situation around in his mind or tries not to think about it at all, tries to forget the accident;

-a driver feels restrain and even stupor when driving a car.

Let's take some examples. That's how participants of traffic accidents describe their state.

Example 1. Woman, 35 years of age, six years driving experience. "Gazel" truck has broken the right mirror of her car when passing too close by. In half a year the accident recurred with the same right mirror and "Gazel" truck. Since then the driver is terrified by "Gazel" tucks. Every time when she sees such a vehicle near her car, her hands start to tremble.

Example 2. Young woman, 25 years of age, no driving experience. She has damaged a friend's car. The accident constantly spins around in her mind so she cannot sleep, feeling fear and panic. She can not overcome her problems herself.

But life never stops, so drivers have to continue driving after accidents although many [3] of them feel discomfort, rigidity and anxiety [4]. In these cases they drive trying to overcome their fear and experiencing a stress.

The mentioned period defines by psyche features and lasts from 3 [5] months to several years [6]. In other words, a driver keeps on harming himself for a long period and systematically ruins his health. This starts to affect his reliability and shows as a increasing fatigue [7].

What should a driver who had an accident know?

First of all it is a sequence of coming out of post-accident syndrome that consists of three main stages:

-stage 1: an adequate assessment of his psychic state;

-stage 2: psychological adaptation (rehabilitation);

-stage 3: restoration of driving skills.

It is necessary to go through these stages methodically. For example, refusing the second stage a driver will take a long time restoring his skills or even never drive again.

The last mentioned factor forces many drivers to drastically change their lives, to change job in case to get rid of negative effects on their lives. This, in turn, affects economical and subsequently psychological aspects of life.

Stage 1. The majority of drivers don't want or cannot assess their psychological postaccidental condition by themselves. This leads to blunting of the sense of danger. This habit can lead to new accidents. In D. Klebelsberg's view the most common factors leading to traffic accidents are: distraction, underestimation of danger, fear, dangerous habits, mistakes in forecasting situation [8].

A professional estimate of psychological state [9] is necessary because driver's reaction to accident effects differs depending on temperament [10]. Inadequate evaluation of psychological state can lead to psychic complications when new experiences combine with already existing problem, and this affects psyche and (or) physiology [11].

In most cases a driver is not able to adequately estimate his psychological condition, so specialized consulting is a necessity.

Stage 2. Officially, the problem of psychological adaptation (rehabilitation) of drivers who experienced traffic accidents has never been raised or discussed and subsequently has never been solved. Today, a driver, as a man who's got a psychological and physical injury, has to solve this problem himself.

Nearly everyone who experienced traffic accidents feel the fear of getting into accident again. That is why some of them never drive again, and those who drive are divided into three categories: 
-drivers who immediately (momentarily) overcame fear,

-drivers who overcame fear during some driving period (from 1 month to 1 year),

-drivers who constantly experience fear when driving.

The most effective method of psychological adaptation is meeting a psychologist, for every person has individual in his emotional state. For example, extraverts prefer fast driving. They blame others for accidents, not themselves. They need to consult a psychologist to overcome their inner infantilism because they are disposed to accidents. On the other hand, they easily adapt after accidents and continue driving practically immediately after. They see accidents as an indispensable element of traffic.

Introverts are much more calm and level-headed drivers. If they get into accidents, they are to experience post-accident syndrome by any means. They are afraid everything what's happened to them repeat and this time it would be much worse.

Psychological rehabilitation includes scrupulous work on consciousness during which psychic post-accident effects and fear of new traffic accidents are removed.

Some drivers after accidents have a panic syndrome that evokes sudden unexpected sense of inevitable terror with such somatic manifestations as dyspnoea, cardiopalmus and fainting. From psychodynamics point of view this is a response to psychic conflict connected to an experienced accident. Such response of anxiety is nothing but a try to mobilize be prepared for a next danger.

Psychic trauma from an accident may cause a physical illness, that's why only professionals, e.g. psychologists, can work with these people. If psychic trauma isn't cured and a driver starts driving again, he becomes a potential killer or a suicide.

Stage 3. Restoring of driving skills should be done concurrently with the work of the instructor and psychologist. It is connected with the fact that the majority of drivers change their style of driving after an accident. Some begin drive better (safer), some - worse. First become more professional drivers [12], others show stalled reaction [13], they become inadequate and stumble even in simple traffic situations [14].

Tension, inevitably in such situations, reduces the speed of reaction. Moreover, this reaction may be inadequate. To remove psychological tension a driver should realize the need to meet a psychologist.

For some drivers an accident works as a cause for raising professional skills, developing such qualities as:

-a skill to model traffic situations,

-a skill to anticipate a turn of events,

- a skill of intelligence analysis.

A period of post-accident syndrome depends on a driver's type of nervous system, that's why there are different methods of restoring a driver. One of these means is a method of regression. First a driver restores a sequence of events before, in time of and after the accident. Then he makes a new chain of events in which the accident never happened and he repeats this "new" story until he himself believes in it.

The second method of psychological adaptation is a method of visual-kinesthetic dissociation (method of disconnection), when you need to disconnect positive and negative experience or to tear today and the day of an accident off. This second method is especially effective when in cases when in every next accident some things are the same like the same place, a car's color, the same weather, etc. An accident became a psychic prescription for a driver, and he cannot come off it without someone's help. Anxiety in certain places (situations) makes a driver to avoid these places (situations), he becomes agoraphobic.

On the basis of complex analysis of conditions of drivers who experienced traffic accidents [15] we propose to introduce the concept of psychological severance of the accident, which means a gradation and duration of emotional problems drivers experience. 
The level of psychological severance will let more adequately estimate the need specialized psychiatry for effective removal of a post-accident syndrome.

The duration of post-accident syndrome depends on:

-accident severance,

-driver's physiological features,

-driver's psychological features.

The main factors influencing the duration of post-accident syndrome: moral, material and psychological (the level of anxiety).

Considering the authors' many years of experience in working with the agenda at hand, we propose the following types of classification of post-accident syndrome:

-according to duration: short, medial and long;

-according to impact: physical, psychological (moral, emotional, etc.);

-according to methods of reducing syndrome: unaided, with a specialized help (psychologist), with the help from relatives, friends, driving instructor;

-according to the effect on a driver: driving without syndrome, driving with some signs of syndrome, cannot drive due to severe syndrome;

-according to intensity of the main panic criteria: expressed panic condition, expressed 1 time daily, a light feel of inner stress;

-according to the type of post-accident syndrome: misgiving, stiffness, worries, fear, stress, disorder, psychic trauma, anxiety, fright, irritation, panic, panic attack, panic disorder, phobia, panic spasm.

\section{Conclusion}

Solving a problem of drivers' post-accident adaptation to further driving is nowadays not only a private problem, but a problem of a state level. The authors consider a great need for creation of psychological centers for estimation of psychological and psychic severance and for rehabilitation of drivers with post-accident syndrome. It is necessary to bind drivers who experienced traffic accidents to provide a certificate by a psychologist to STSI or an attestation center, in which syndrome severance and a number of hours with a qualified specialist are indicated.

The solution of this problem should lessen an accident quantity and improve traffic safety.

\section{References}

1. P.A. Pegin,Avtotransportnayapsikhologiya. M.: Izdatel'skiytsentr «Akademiya», (2014)

2. P.A. Pegin,Psikhologicheskieetapystanovleniyavoditelya-professionala. Avtomobil'nyy transport Dal'negoVostokaiSibiri 2004. p. 49-55. (2004)

3. P.A. Pegin,Vliyanieoperativnoypamyativoditelyanabezopasnost' dorozhnogodvizheniya.Dal'niy Vostok. Avtomobil'nyedorogiibezopasnost' dvizheniya.Vypusk 1. p. 38-44. (2001)

4. P.A. Pegin,S.N. Starov.Novyemetodybor'by s narushitelyamipravildorozhnogodvizheniya. Uchenyezametki TOGU. Volume 7. № 4. p. 488-490. (2016)

5. M.Obrien,Psychiatric consequences of road traffic accidents. Loss of memory is protective. British medical journal. Tom 307 Volume 6914. p. 1283-1283. (1993) 
6. R.Mayou,B.Bryant,R.Duthie. Psychiatric consequences of road traffic accidents. British medical journal. Tom 307. Volume 6905. p. 647-651. (1993)

7. L.Precht, A.Keinath, J.F. Krems. Identifying the main factors contributing to driving errors and traffic violations - Results from naturalistic driving data. Transportation Research Part F: Traffic Psychology and Behaviour.Volume 49. Pages 49-92. (2017)

8. D.Klebel'sberg, Transportnayapsikhologiya. M.: Transport, (1989)

9. A.N.Romanov,P.A. Pegin,Nadezhnost' voditelya. Khabarovsk. PNU. (2006)

10. R.V.Rotenberg,Osnovynadezhnostisistemyvoditel - avtomobil-doroga-sreda. M.: Mashinostroenie, (1986)

11. P.Pegin,E.Sitnichuk,The Effect of Sun Glare: Concept, Characteristics, Classification.Transportation Research Procedia.Volume 20. p. 474-479. (2017)

12. P.A.Pegin,Obucheniebezopasnostidvizheniyaibezopasnomupovedeniyunadoroge $v$ techeniezhizni.Avtomobil'nyy transport Dal'negoVostoka. p. 112-118. (2012)

13. P.A.Pegin,K.A.Mamonova,Perspektivyispol'zovaniya v Rossiiprogrammkorrektirovkivoditeley - narushiteleypravildorozhnogodvizheniya. Uchenyezametki TOGU. Tom 5. № 4. p. 1299-1303. (2014)

14. P.A.Pegin,S.I.Karpenko,O.Yu.IshchenkoKursydopolnitel'nogoobucheniyanarushiteley pravildorozhnogodvizheniya (naprimereAvstrii).

Sovershenstvovanieorganizatsiidorozhnogodvizheniyaiperevozokpassazhirovigruzov. Volume 8. p. 128-134. (2016)

15. P.A.Pegin,N.A. Pegin,Psikhofiziologicheskieprichinydorozhnotransportnykhproisshestviy $v$ usloviyakhDal'negoVostoka.

Povyshenieeffektivnostiikachestvastroitel'stvairemontaavtomobil'nykhdorog v Dal'nevostochnomregione. p. 96-102. (2001) 